Check for updates

Cite this: RSC Adv., 2017, 7, 35528

\section{Synthesis, crystal structure and remote allosteric binding properties of cone thiacalix[4] pseudocrown receptors bearing anthraquinone function and different arms $\dagger$}

\author{
Xue-Xin Lv, \$ Qian Wang, Li-Jing Zhang, Ling-Ling Liu, Mei Zhao \\ and Dian-Shun Guo (D) *
}

\begin{abstract}
Herein, three novel cone thiacalix[4]pseudocrown receptors 1-3, bearing anthraquinone and triazole functions as well as different side arms, were successfully synthesized via a double click reaction as the key step. Their recognition properties have been fully evaluated using optical, electrochemical, and theoretical methods. Receptor 1 features high selectivity for $\mathrm{Pb}^{2+}$, whereas receptor 2 can optically recognize $\mathrm{Zn}^{2+}$ in the presence of $\mathrm{Cd}^{2+}$. This difference of binding specificity to metal ions may be ascribed to the remote tuning effect from the side arms connected to the lower rim of thiacalix[4]arene that realizes the accommodation of binding specificity. Moreover, the plausible coordination modes have been presented.
\end{abstract}

Received 31st May 2017

Accepted 1st July 2017

DOI: $10.1039 / \mathrm{c} 7 \mathrm{ra06083a}$

rsc.li/rsc-advances

\section{Introduction}

The design and synthesis of optical and redox-active receptors for the efficient detection of environmentally and biologically relevant ionic species is a challenging topic. ${ }^{1-5}$ This type of receptors combines signaling reporters with well-defined recognition centers to enable facile detection of ion binding through optical and electrochemical techniques. In particular, the selective detection of $\mathrm{Zn}^{2+}$ and $\mathrm{Pb}^{2+}$ ions is one of the most interesting projects as the former plays key roles in many biochemical processes ${ }^{6-10}$ and the latter is an ongoing danger to the human health, especially to children. ${ }^{11-14}$

Thiacalix[4]arenes are a kind of versatile scaffolds for highly organized receptors because of their specific affinity and allosteric features in molecular recognition. ${ }^{15-21}$ In recent years, many optical receptors have been designed and synthesized based on the thiacalix[4]arene scaffold. Excellent examples include quinoline, rhodamine, naphthalene, pyrene, as well as coumarin-appended thiacalix[4]arene receptors. ${ }^{22-26}$ On the other hand, to date, less attention has been

\footnotetext{
College of Chemistry, Chemical Engineering and Materials Science, Collaborative Innovation Center of Functionalized Probes for Chemical Imaging in Universities of Shandong, Shandong Normal University, Jinan 250014, P. R. China. E-mail: chdsguo@sdnu.edu.cn; Fax: +86 531 86928773; Tel: +8653186180743

$\dagger$ Electronic supplementary information (ESI) available: Spectral characterisation of compounds; protocols for UV-vis absorption, fluorescence emission spectra, ${ }^{1} \mathrm{H}$ NMR and electrochemical titrations, as well as the calculated structure. CCDC 863160. For ESI and crystallographic data in CIF or other electronic format see DOI: $10.1039 / \mathrm{c} 7 \mathrm{ra06083a}$

$\ddagger$ Both authors contributed equally to the work.
}

paid to developing the corresponding redox active receptors. $^{27-29}$ In particular, there is a paucity of optical and redoxactive receptors involving thiacalix[4]arene. ${ }^{27}$ Thiacalix[4] crown, with one or two crown ether(s) at the lower rim of the thiacalix[4]arene unit, possesses various donor atoms within its crown ring and can accommodate desired substrates. ${ }^{18,30,31}$ Thus, it is essential to develop optical and redox-active thiacalix[4]crowns as candidate receptors for the highly selective and sensitive detection of desired substrates as they provide facile access to multiple monitoring.

Anthraquinone can be used as a signal reporter in sensors because its optical and electrochemical properties can be significantly perturbed by chemical stimuli. $^{32}$ The $9,10-$ anthraquinone probe is known to exhibit a pronounced color change and remarkable potential shift when it interacts with some metal ions. ${ }^{33,34}$ Recently, the click reaction has become a powerful strategy for molecular linking in synthetic chemistry. ${ }^{35-37}$ In view of these precedents, we combined the thiacalix[4]arene scaffold and 9,10-anthraquinone function through the double click reaction to construct new thiacalix[4] pseudocrown receptors, 1-3 (Scheme 1), in which the 9,10anthraquinone group acted as an optical and electrochemical reporter, two 1,2,3-triazole rings acted as both linkers and potential binding sites, and various side arms could remotely regulate the binding specificity. Their ability of binding metal ions has been assessed by optical, electrochemical, and theoretical techniques. 

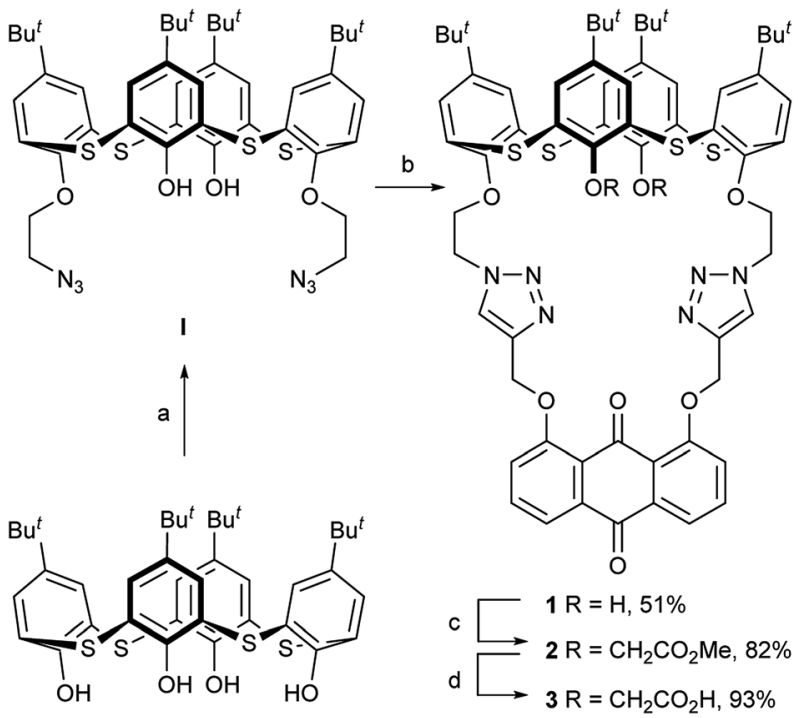

Scheme 1 Reagents and conditions: (a) $\mathrm{N}_{3} \mathrm{CH}_{2} \mathrm{CH}_{2} \mathrm{OTs}, \mathrm{KI}, \mathrm{K}_{2} \mathrm{CO}_{3}$, acetone, and reflux. (b) 1,8-bis(2-propynyloxy)anthraquinone, $\mathrm{Et}_{3} \mathrm{~N}$, Cul, THF, $\mathrm{H}_{2} \mathrm{O}$, and $60^{\circ} \mathrm{C}$. (c) $\mathrm{BrCH}_{2} \mathrm{CO}_{2} \mathrm{Me}, \mathrm{NaH}$, THF, and rt. (d) $\mathrm{KOH}$, $\mathrm{H}_{2} \mathrm{O}, \mathrm{THF}$, and $\mathrm{rt}$.

\section{Results and discussion}

\subsection{Synthesis and characterization of the receptors 1-3}

The synthesis of the receptors 1-3 is shown in Scheme 1. Treatment of $p$-tert-butylthiacalix[4]arene with 2-azidoethyl-4methylbenzene-sulfonate and $\mathrm{KI}$ in an acetone solution using anhydrous $\mathrm{K}_{2} \mathrm{CO}_{3}$ as a base furnished the intermediate $\mathbf{I}$ (a cone conformer) in $56 \%$ yield. Then, the double 1,3-dipolar cycloaddition ring-closure reaction of $\mathbf{I}$ with 1,8-bis(2-propynyloxy) anthraquinone catalyzed by $\mathrm{CuI}$ yielded the thiacalix[4]pseudocrown receptor 1 in 51\% yield. Receptor 2 was obtained in good yield ( $82 \%$ ) via treatment of $\mathbf{1}$ with methyl bromoacetate in the presence of $\mathrm{NaH}$ in a dry THF solution. Hydrolysis of the ester functions in 2 with $\mathrm{KOH}$ in THF provided the corresponding receptor 3 in 93\% yield. All the new thiacalix[4]arene derivatives were fully characterized by ${ }^{1} \mathrm{H}$ NMR, ${ }^{13} \mathrm{C}$ NMR, IR, MS, and elemental analysis.

The NMR spectral data indicate that the receptors 1-3 and intermediate I feature the cone conformation, ${ }^{21}$ showing two singlet peaks at 1.38-0.69 ppm in the ${ }^{1} \mathrm{H}$ NMR and two doublet peaks at $31.5-30.7 \mathrm{ppm}$ in the ${ }^{13} \mathrm{C}$ NMR spectra. To further examine the 3D structure of thiacalix[4]pseudocrown receptors, the single crystal structure of 2 (Fig. 1) was determined by X-ray crystallography. Analysis of the data reveals that receptor 2 adopts a pinched cone conformation. The dihedral angles between the phenolic rings and the virtual plane defined by the four bridging sulfur atoms are 33.3(0), 56.0(1), 88.7(0), and $83.7(1)^{\circ}$. The average distance between two vicinal sulfur atoms is $5.523 \AA$ A fitting the previously reported values. ${ }^{38}$ The two 1,2,3triazole rings exhibit the same orientation, with dissimilar tilted angles. The dihedral angels between the triazole rings (N1-N2$\mathrm{N} 3-\mathrm{C} 14-\mathrm{C} 13)$ and (N4-N5-N6-C31-C32) and the anthraquinone ring (C23-C24-C26-C27-C28-C29) are 48.9(0) and

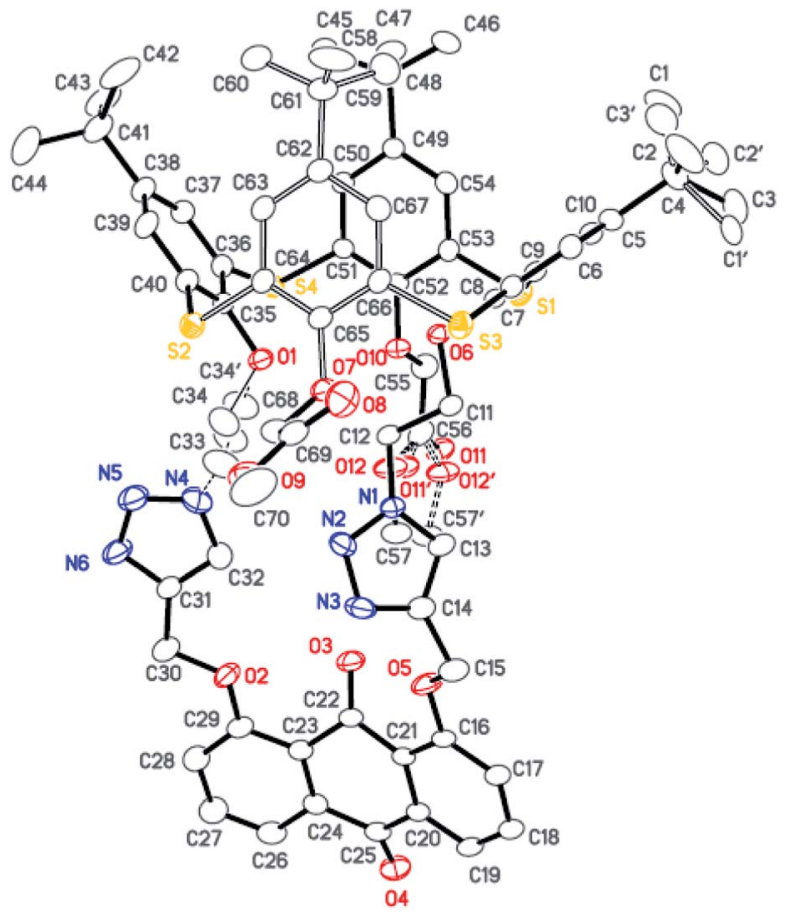

Fig. 1 Crystal structure of 2, showing the atom-labelling scheme and the disordered atoms. Displacement ellipsoids are drawn at the 30\% probability level. Hydrogen atoms and solvent molecules are omitted for clarity.

11.2(1) ${ }^{\circ}$, respectively. The anthraquinone unit in 2 shows a vlike shape, in which two outer phenyl rings make an interplanar angle of 21.1(1) ${ }^{\circ} .^{39}$ Note that the intraannular carbonyl oxygen atom $\mathrm{O} 3$ is strongly bent out of the anthraquinone plane. This distortion may be ascribed to the intramolecular interactions between the carbonyl oxygen atom $\mathrm{O} 3$ and two ether bridges. The $\mathrm{O} 3 \cdots \mathrm{O} 2$ and $\mathrm{O} 3 \cdots \mathrm{O} 5$ distances are $2.665(6)$ and 2.674(7) $\AA$, respectively, much shorter than the sum of the van der Waals radii of two oxygen atoms $(3.04 \AA) .{ }^{40}$ In the solid state, the molecule 2 possesses a well pre-organized array of oxygen atoms and nitrogen atoms of the triazole rings that are favorable for interaction with suitable guest species.

\subsection{UV-vis and fluorescence studies}

The recognition behavior of the receptors towards various cations was first evaluated by UV-vis and fluorescence spectroscopy. UV-vis spectroscopy of 1 and 2 in $\mathrm{CH}_{2} \mathrm{Cl}_{2} / \mathrm{MeCN}(1: 1$, $\mathrm{v} / \mathrm{v}$ ) solution revealed absorption maxima at 372 and $376 \mathrm{~nm}$ (Fig. S1, ESI $\dagger$ ), corresponding to the anthraquinone probe. ${ }^{34}$ The metal-binding properties of both receptors have been investigated by monitoring the absorption changes upon the addition of perchlorate salts of $\mathrm{Li}^{+}, \mathrm{Na}^{+}, \mathrm{K}^{+}, \mathrm{Cs}^{+}, \mathrm{Mg}^{2+}, \mathrm{Ca}^{2+}$, $\mathrm{Co}^{2+}, \mathrm{Ni}^{2+}, \mathrm{Ag}^{+}, \mathrm{Cu}^{2+}, \mathrm{Hg}^{2+}, \mathrm{Zn}^{2+}, \mathrm{Cd}^{2+}$, and $\mathrm{Pb}^{2+}$. As shown in Fig. 2, upon the addition of $\mathrm{Zn}^{2+}$ ions to the solution of $\mathbf{1}$, the absorption at $372 \mathrm{~nm}$ shifted to $399 \mathrm{~nm}$ with a significant absorbance enhancement. This change is probably due to the coordination of 1 with $\mathrm{Zn}^{2+}$. The fact is responsible for the turning of pale-yellow color into deep-yellow one that can be 


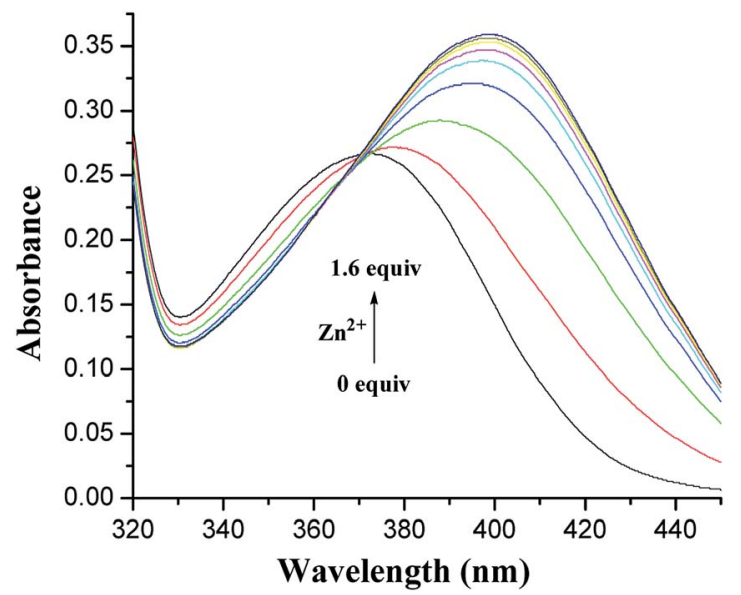

Fig. 2 Changes in the absorption spectrum of $1\left(5.0 \times 10^{-5} \mathrm{M}\right)$ in $\mathrm{CH}_{2} \mathrm{Cl}_{2} / \mathrm{MeCN}(1: 1, \mathrm{v} / \mathrm{v})$ upon the addition of increasing amounts of $\mathrm{Zn}^{2+}$.

detected by the naked eye. The Job's plot for the binding of 1 with $\mathrm{Zn}^{2+}$ (Fig. S2, ESI $\dagger$ ) provides a 1:1 stoichiometry. The association constant $\log K_{\mathrm{s}}$ obtained by fitting the titration data is $5.73 \mathrm{M}^{-1}$. A similar behavior was observed for $\mathrm{Cd}^{2+}$ and $\mathrm{Pb}^{2+}$ ions, which exhibited a smaller shift to 385 and $387 \mathrm{~nm}$ (Fig. S3 and $\mathrm{S} 4, \mathrm{ESI} \dagger$ ), respectively. No obvious changes were observed in the UV-vis spectra upon the addition of other metal ions. Under the same conditions, receptor 2 exhibited similar but smaller changes in spectral absorption in the presence of $\mathrm{Zn}^{2+}$, $\mathrm{Cd}^{2+}$, and $\mathrm{Pb}^{2+}$ ions (Fig. S5-S7, ESI $\dagger$ ). However, the association constants for $\mathbf{1}$ and $\mathbf{2}$ were nearly parallel (Table S1, ESI $\dagger$ ). Similarly, the Job's plot for the binding of 2 with $\mathrm{Pb}^{2+}$ (Fig. S8, ESI $\dagger$ ) also provided a $1: 1$ stoichiometry.

Assay of the ion affinity was also performed by monitoring the changes originating from the fluorescence intensity of 1-3 induced by metal ions. A systematic change in the fluorescence spectra associated with the addition of different metal ions is shown in Fig. 3.

In the fluorescence spectra, 1 exhibited a weak fluorescence with an emission band at $427 \mathrm{~nm}$ under excitation at $375 \mathrm{~nm}$ (Fig. S9, ESI $\dagger$ ). A clear fluorescence enhancement (ca. 140\%, Fig. 4) was observed upon the addition of $\mathrm{Pb}^{2+}$ at $465 \mathrm{~nm}$, whereas only $42 \%$ and $33 \%$ enhancements were obtained in the cases of $\mathrm{Zn}^{2+}$ and $\mathrm{Cd}^{2+}$ at $428 \mathrm{~nm}$, respectively. Under identical conditions, no increase in the fluorescent emission was detected upon the addition of other metal ions involving $\mathrm{Li}^{+}, \mathrm{Na}^{+}, \mathrm{K}^{+}$, $\mathrm{Cs}^{+}, \mathrm{Mg}^{2+}, \mathrm{Ca}^{2+}, \mathrm{Co}^{2+}, \mathrm{Ni}^{2+}, \mathrm{Ag}^{+}, \mathrm{Cu}^{2+}$, and $\mathrm{Hg}^{2+}$.

The red shift in the emission band of 1 could be assigned to the ICT ${ }^{41,42}$ occurred via the coordination of 1 with $\mathrm{Pb}^{2+}$. When $\mathrm{Pb}^{2+}$ ion strongly interacts with the lone pair electrons of the intraannular carbonyl oxygen atom with the aid of two triazole rings (this has been ascertained by the electrochemical behavior of the $\left[\mathbf{1} \cdot \mathrm{Pb}^{2+}\right]$ complex hereinafter), charge transfer from the 1,8-oxygen atoms to the electron-deficient carbonyl group becomes stronger. The enhancement of the fluorescence intensity is presumably ascribed to the metal ion binding with 1,2,3-triazole rings followed by PET suppression. ${ }^{\mathbf{4 3 4 4}}$ This

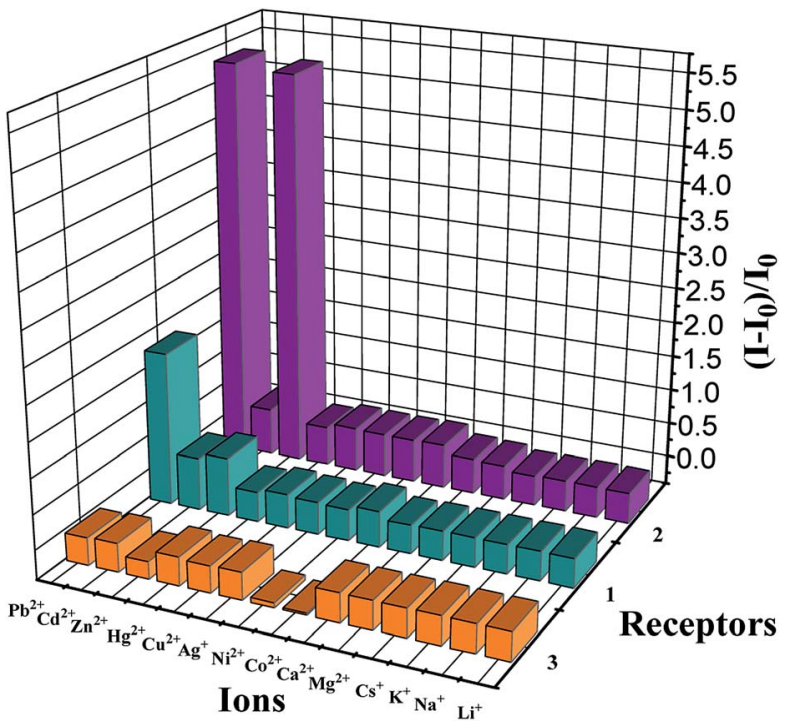

Fig. 3 Changes in the fluorescence emission intensity of 1, $2(5.0 \times$ $\left.10^{-5} \mathrm{M}\right)$ in $\mathrm{CH}_{2} \mathrm{Cl}_{2} / \mathrm{MeCN}(1: 1, \mathrm{v} / \mathrm{v})$, and $3\left(5.0 \times 10^{-5} \mathrm{M}\right)$ in $\mathrm{THF} / \mathrm{H}_{2} \mathrm{O}$ $(9: 1, \mathrm{v} / \mathrm{v})$ at $\mathrm{pH} 7.4$ in HEPES after the addition of 1.0 equiv. metal ions. $I_{0}$ and $/$ refer to the fluorescence emission intensity of $1-3$ and that after the addition of metal ions, respectively.

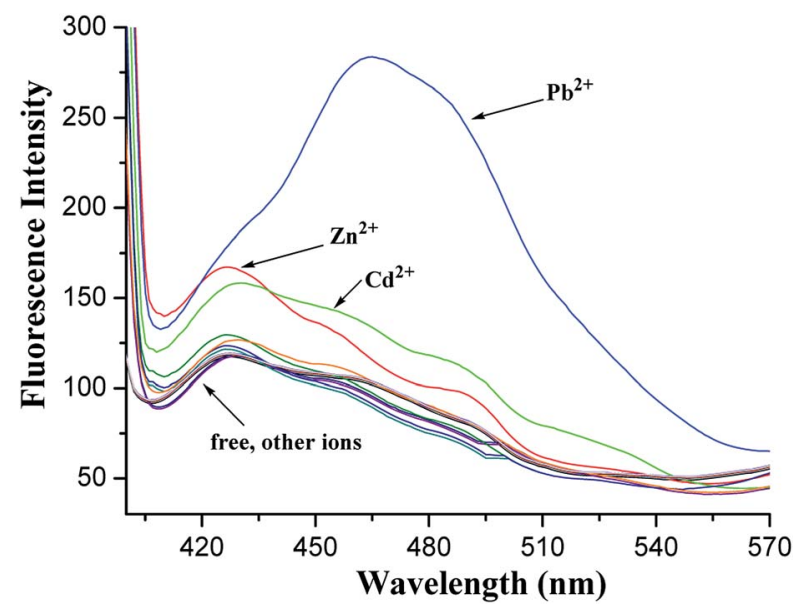

Fig. 4 Fluorescence spectra of $1\left(5.0 \times 10^{-5} \mathrm{M}\right)$ in $\mathrm{CH}_{2} \mathrm{Cl}_{2} / \mathrm{MeCN}(1: 1$, $\mathrm{v} / \mathrm{v})$ upon the addition of perchlorate salts of $\mathrm{Li}^{+}, \mathrm{Na}^{+}, \mathrm{K}^{+}, \mathrm{Cs}^{+}, \mathrm{Mg}^{2+}$, $\mathrm{Ca}^{2+}, \mathrm{Co}^{2+}, \mathrm{Ni}^{2+}, \mathrm{Ag}^{+}, \mathrm{Cu}^{2+}, \mathrm{Hg}^{2+}, \mathrm{Zn}^{2+}, \mathrm{Cd}^{2+}$, and $\mathrm{Pb}^{2+}$ under an excitation at $375 \mathrm{~nm}$.

supposition has been initially confirmed by the following theoretical calculations.

Fluorescence titration of 1 with $\mathrm{Pb}^{2+}$ ions in $\mathrm{CH}_{2} \mathrm{Cl}_{2} / \mathrm{MeCN}$ $(1: 1, v / v)$ was also performed. Fig. 5 shows the changes in the fluorescence emission intensity of $\mathbf{1}$ upon the addition of increasing amounts of $\mathrm{Pb}^{2+}$ ions. Binding analysis using the method of continuous variations (Job's plot) ${ }^{45,46}$ established a $1: 1$ stoichiometry for the $\left[1 \cdot \mathrm{Pb}^{2+}\right]$ complex (Fig. 5 , inset). The association constant $\log K_{\mathrm{s}}$ was further determined to be 5.27 $\mathrm{M}^{-1}$ by fitting the titration result. ${ }^{47}$

The possible interferences by other metal ions were assessed through competitive experiments. The fluorescence changes of 


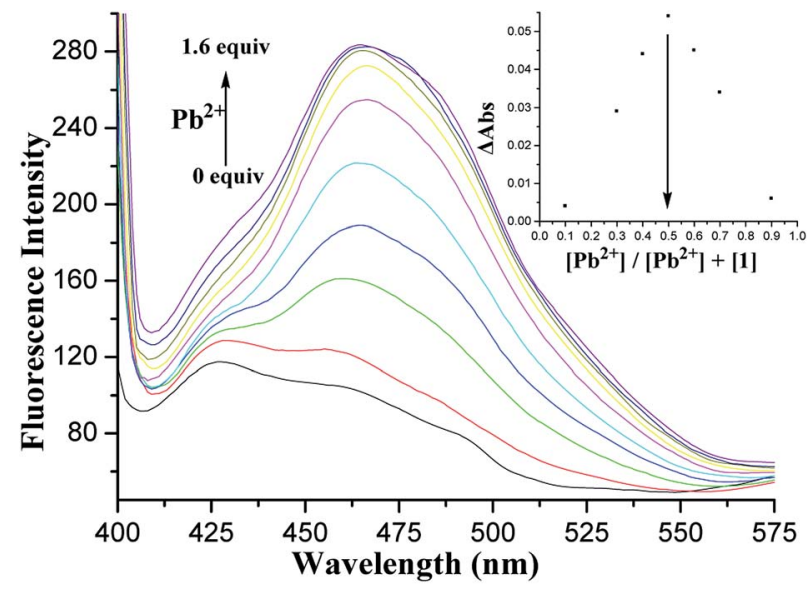

Fig. 5 Changes in the fluorescence emission spectrum of 1 $\left(5.0 \times 10^{-5} \mathrm{M}\right)$ in $\mathrm{CH}_{2} \mathrm{Cl}_{2} / \mathrm{MeCN}(1: 1, \mathrm{v} / \mathrm{v})$ upon the addition of $\mathrm{Pb}^{2+}$ ions under an excitation at $375 \mathrm{~nm}$. The inset shows the Job's plot of 1 with $\mathrm{Pb}^{2+}$.

1 in $\mathrm{CH}_{2} \mathrm{Cl}_{2} / \mathrm{MeCN}(1: 1, \mathrm{v} / \mathrm{v})$ solution were measured via treatment of 1.0 equiv. $\mathrm{Pb}^{2+}$ ions in the presence of 50 equiv. of other interfering metal ions involving $\mathrm{Li}^{+}, \mathrm{Na}^{+}, \mathrm{K}^{+}, \mathrm{Cs}^{+}, \mathrm{Mg}^{2+}$, $\mathrm{Ca}^{2+}, \mathrm{Co}^{2+}, \mathrm{Ni}^{2+}, \mathrm{Ag}^{+}, \mathrm{Cu}^{2+}, \mathrm{Hg}^{2+}, \mathrm{Zn}^{2+}$, and $\mathrm{Cd}^{2+}$. All the interfering metal ions showed little or no interference with the detection (Fig. 6, green bars), except $\mathrm{Zn}^{2+}$ and $\mathrm{Cd}^{2+}$ that quenched the fluorescence to some degree. This unique selectivity of 1 to $\mathrm{Pb}^{2+}$ may be ascribed to the result of the combination of the suitable coordination geometry of the chelating receptor, the radius of $\mathrm{Pb}^{2+}$, and the nitrogen-affinity character of $\mathrm{Pb}^{2+}$, indicating that receptor $\mathbf{1}$ can be potentially applied as a probe for $\mathrm{Pb}^{2+}$ ions.

Similar to 1 , receptor 2 , in which only two $\mathrm{OH}$ groups were transformed into $\mathrm{OCH}_{2} \mathrm{CO}_{2} \mathrm{Me}$ moieties via the $\mathrm{O}$-alkylation

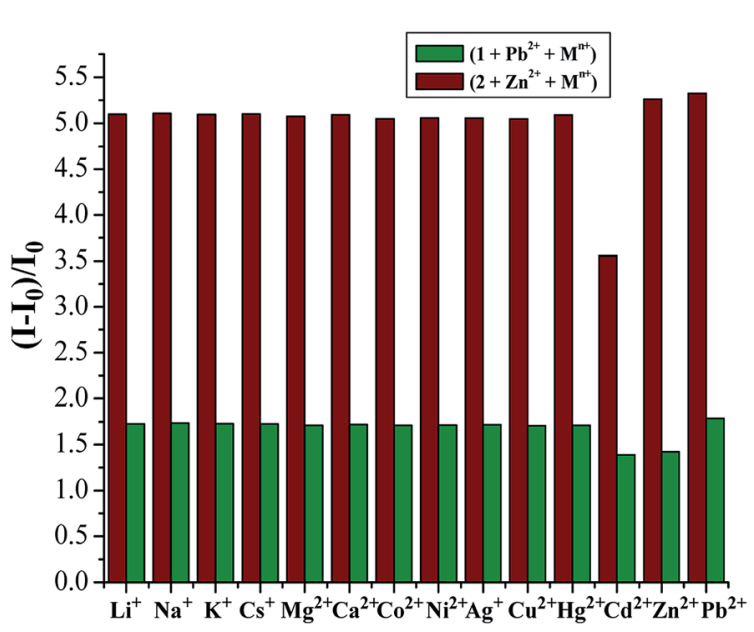

Fig. 6 Competitive studies of $\left[1 \cdot \mathrm{Pb}^{2+}\right]$ and $\left[2 \cdot \mathrm{Zn}^{2+}\right]$ in $\mathrm{CH}_{2} \mathrm{Cl}_{2} / \mathrm{MeCN}$ $(1: 1, v / v)$ with different cations. Green bars: selectivity of $1\left(5.0 \times 10^{-5}\right.$ M) towards $\mathrm{Pb}^{2+}$ upon the addition of different metal ions. Purplish red bars: selectivity of $2\left(5.0 \times 10^{-5} \mathrm{M}\right)$ towards $\mathrm{Zn}^{2+}$ upon the addition of different metal ions. $I_{0}$ and $/$ refer to the fluorescence emission intensity of 1 and 2 and that after the addition of metal ions, respectively. reaction, showed a weak fluorescence with an emission band at $428 \mathrm{~nm}$ under excitation at $375 \mathrm{~nm}$ (Fig. S9, ESI $\dagger$ ). A 4-fold fluorescence enhancement was obtained in the presence of $\mathrm{Pb}^{2+}$ ions at $465 \mathrm{~nm}$, and the binding constant $\log K_{\mathrm{s}}$ was $5.82 \mathrm{M}^{-1}$ (Fig. S10, ESI $\dagger$ ), which was similar to the binding property of receptor 1 for $\mathrm{Pb}^{2+}$ ions. To our surprise, upon the addition of $\mathrm{Zn}^{2+}$ ions, 2 displayed a 3.75-fold fluorescence enhancement at $476 \mathrm{~nm}$. Fig. 7 shows the detailed fluorescence changes of 2 upon the gradual addition of $\mathrm{Zn}^{2+}$ ions. The Job's plot (Fig. 7, inset) for the binding of 2 with $\mathrm{Zn}^{2+}$ shows a $1: 1$ stoichiometry, whereas the association constant $\log K_{\mathrm{s}}$ of the $\left[2 \cdot \mathrm{Zn}^{2+}\right]$ complex has been calculated to be $5.56 \mathrm{M}^{-1}$. This different selectivity of 2 may be attributed to the influence of two ester functions at the lower rim that can offer better flexibility of the thiacalix[4]arene unit to remotely regulate the size of its crown cavity as the ester functions cannot fix the structure via intramolecular hydrogen bonding interactions. ${ }^{21}$

In view of the better selectivity of 2 , we tried to develop a chemosensor that could discriminate $\mathrm{Zn}^{2+}$ from $\mathrm{Cd}^{2+}$ to some extent, considering their similarity in chemical properties. Therefore, the competitive experiments of $\mathrm{Zn}^{2+}$ mixed with other metal ions were performed (Fig. 6, purplish red bars). As can be seen, among the metal ions tested herein, no significant spectral changes were observed upon the addition of alkali metal ions and some transition metal ions except for the case of $\mathrm{Cd}^{2+}$, where partial quenching was detected. The design of receptors that offer high $\mathrm{Zn}^{2+} / \mathrm{Cd}^{2+}$ selectivity is one of the current challenges in cation recognition chemistry. ${ }^{48-50}$ Thus, the ability to optically recognize $\mathrm{Zn}^{2+}$ in the presence of $\mathrm{Cd}^{2+}$ is an interesting feature of this thiacalix[4]pseudocrown receptor.

\subsection{Electrochemistry studies}

The recognition properties of $\mathbf{1}$ and $\mathbf{2}$ towards the abovementioned metal ions were also proven by monitoring the electrochemical behavior of $\mathbf{1}$ and $\mathbf{2}$ in the absence and presence of metal ions. Their electrochemical properties were

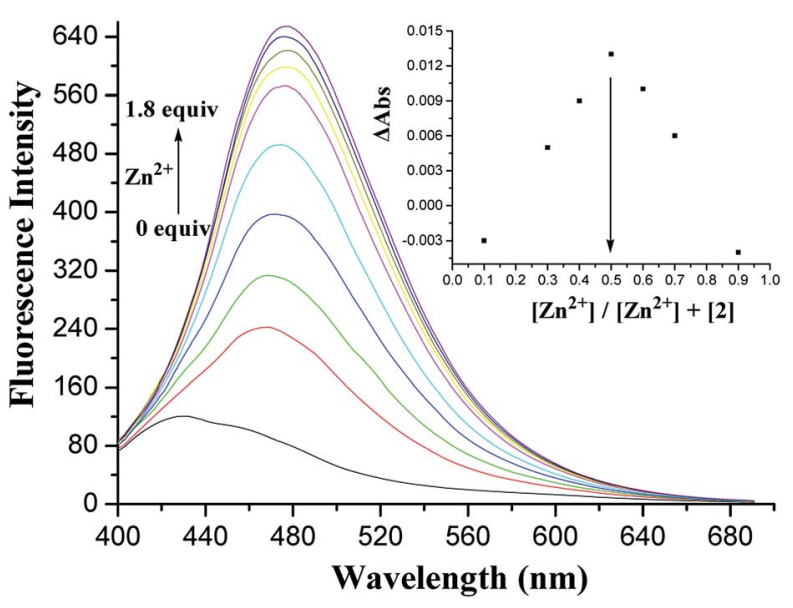

Fig. 7 Changes in the fluorescence emission spectrum of $2(5.0 \times$ $\left.10^{-5} \mathrm{M}\right)$ in $\mathrm{CH}_{2} \mathrm{Cl}_{2} / \mathrm{MeCN}(1: 1, \mathrm{v} / \mathrm{v})$ upon the addition of $\mathrm{Zn}^{2+}$ ions under an excitation at $375 \mathrm{~nm}$. The inset shows the Job's plot of 2 with $\mathrm{Zn}^{2+}$. 
initially measured using cyclic voltammetry (CV) in $\mathrm{CH}_{2} \mathrm{Cl}_{2} /$ $\operatorname{DMSO}(3: 1, \mathrm{v} / \mathrm{v})$ containing $0.1 \mathrm{M} n-\mathrm{Bu}_{4} \mathrm{NPF}_{6}$ as the supporting electrolyte. The CV curves showed a quasi-reversible redox couple that became more and more irreversible upon the addition of metal ions. Alternatively, differential pulse voltammetry (DPV) was utilized. The cathodic peaks $\left(E_{\mathrm{pc}}\right)$ at -0.95 and $-0.98 \mathrm{~V}$ were observed for $\mathbf{1}$ and $\mathbf{2}$, respectively, which corresponded to the successive one-electron transfers to the anthraquinone moiety of the receptors. Negligible changes in the DPV voltammograms of both receptors were observed upon the addition of $\mathrm{Li}^{+}, \mathrm{Na}^{+}, \mathrm{K}^{+}, \mathrm{Cs}^{+}, \mathrm{Mg}^{2+}, \mathrm{Ca}^{2+}, \mathrm{Co}^{2+}, \mathrm{Ni}^{2+}, \mathrm{Ag}^{+}$, $\mathrm{Cu}^{2+}$, and $\mathrm{Hg}^{2+}$ metal ions, whereas significant modifications were found upon the addition of $\mathrm{Zn}^{2+}, \mathrm{Cd}^{2+}$, and $\mathrm{Pb}^{2+}$ ions (Fig. 8). On stepwise addition of $\mathrm{Zn}^{2+}$ ions to the receptor $\mathbf{1}$, a clear evolution of the reduction wave to $E_{\mathrm{pc}}=-0.83 \mathrm{~V}\left(\Delta E_{\mathrm{pc}}=\right.$ $120 \mathrm{mV}$ ) with an increase in the intensity of the initial wave was observed (Fig. S11, ESI $\dagger$ ), and the maximum shift of DPV was obtained with 1.0 equiv. $\mathrm{Zn}^{2+}$ ions. This result confirms the formation of the $\left[\mathbf{1} \cdot \mathrm{Zn}^{2+}\right]$ complex. Receptor $\mathbf{1}$ also showed the shifts of the reduction waves in the presence of $\mathrm{Cd}^{2+}$ and $\mathrm{Pb}^{2+}$ ions, and new reduction waves at $E_{\mathrm{pc}}=-0.87 \mathrm{~V}\left(\Delta E_{\mathrm{pc}}=80 \mathrm{mV}\right)$ and $E_{\mathrm{pc}}=-0.88 \mathrm{~V}\left(\Delta E_{\mathrm{pc}}=70 \mathrm{mV}\right)$ positively shifted (Fig. S12, ESI $\dagger$ ). In the presence of $\mathrm{Zn}^{2+}, \mathrm{Cd}^{2+}$, and $\mathrm{Pb}^{2+}$ ions, similar results were obtained for 2 (Fig. S13, ESI $\dagger$ ). Based on the magnitude of these observed shifts, it can be speculated that complexation exerts a more powerful effect on the anthraquinone moiety and two triazole rings than on the thiacalix[4]arene cavity. The electrochemical selectivity of $\mathbf{1}$ and $\mathbf{2}$ may be attributed to the compatibility between the receptors and metal ions.

\section{$2.4 \quad{ }^{1}$ H NMR titrations}

To explore the $1: 1$ stoichiometry and coordination modes, ${ }^{1} \mathrm{H}$ NMR titration experiments were carried out for receptor $2(9.0 \times$ $\left.10^{-3} \mathrm{M}\right)$ in $\mathrm{CDCl}_{3}$ and $\mathrm{Zn}\left(\mathrm{ClO}_{4}\right)_{2}\left(3.0 \times 10^{-1} \mathrm{M}\right)$ in $\mathrm{CD}_{3} \mathrm{CN}$ at $25{ }^{\circ} \mathrm{C}$ (Fig. 9). The complexation process of 2 induced not only

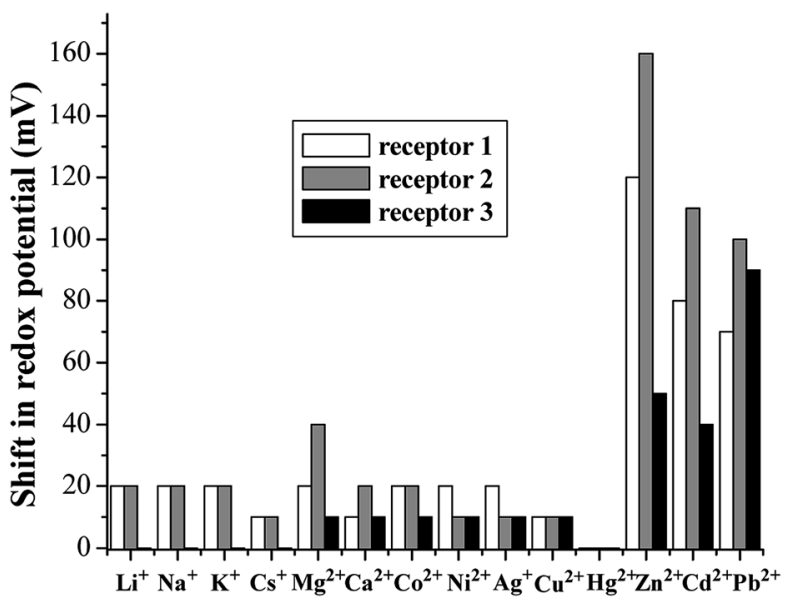

Fig. 8 Shifts in the redox potential of 1-3 induced by the addition of 1.0 equiv. metal ions. The DPV of 1 and 2 were measured in $\mathrm{CH}_{2} \mathrm{Cl}_{2} /$ DMSO $(3: 1, v / v)$, and that of 3 was measured in $\mathrm{THF} / \mathrm{H}_{2} \mathrm{O}(9: 1, \mathrm{v} / \mathrm{v})$ at $\mathrm{pH} 7.4$ in HEPES.
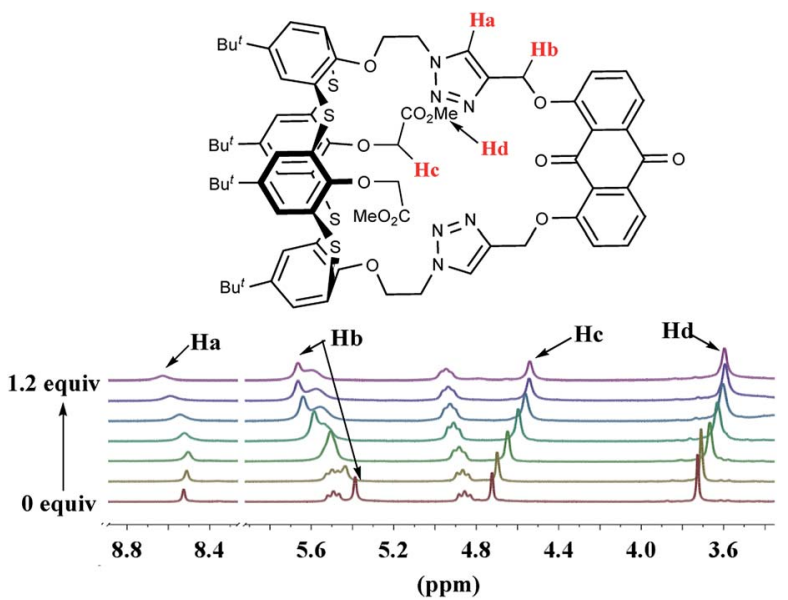

Fig. 9 Partial ${ }^{1} \mathrm{H}$ NMR $(300 \mathrm{MHz})$ spectra of $2\left(9.0 \times 10^{-3} \mathrm{M}\right)$ in $\mathrm{CDCl}_{3}$ upon the addition of increasing amounts of $\mathrm{Zn}\left(\mathrm{ClO}_{4}\right)_{2}\left(3.0 \times 10^{-1} \mathrm{M}\right)$ in $\mathrm{CD}_{3} \mathrm{CN}$.

noticeable downfield changes in the chemical shifts of triazole$\mathrm{H}(\Delta \delta=0.104 \mathrm{ppm})$ and $\mathrm{OCH}_{2}(\Delta \delta=0.278 \mathrm{ppm})$ linked to the anthraquinone unit but also relatively large upfield shifts in $\mathrm{OCH}_{2}(\Delta \delta=0.183 \mathrm{ppm})$ and $\mathrm{CO}_{2} \mathrm{Me}(\Delta \delta=0.130 \mathrm{ppm})$ of $\mathrm{OCH}_{2} \mathrm{CO}_{2} \mathrm{Me}$. The downfield-shift spectral changes of the triazole ring protons and $\mathrm{OCH}_{2}$ linked to the anthraquinone unit can indicate that the two triazole rings and the anthraquinone unit are acting as effective binding sites in the complexation event; however, the upfield-shift changes show the adjustment of the thiacalix[4]arene conformation. The titration isotherm matches a $1: 1$ bonding model, which is in line with the results obtained by the UV-vis titrations and fluorescence titrations.

\subsection{Theoretical studies}

To understand the remotely regulated effect resulting from the different arms as well as the binding specificity of receptors 1 and 2, their structures were initially optimized via theoretical calculations at the AM1/3-21G level of theory. ${ }^{51,52}$ In the optimized structures of 1 and 2 (Fig. 10), two triazole rings exhibit the same orientation, and the anthraquinone unit has a v-like shape, which is similar to the crystal structure of 2 . The main

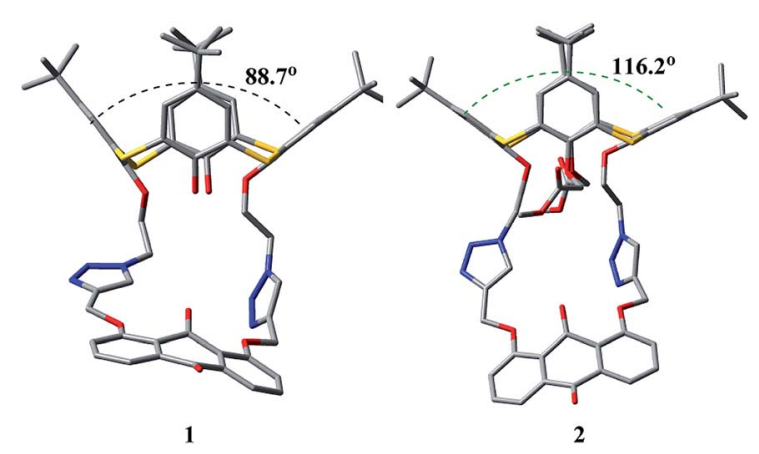

Fig. 10 Optimized structures (AM1/3-21G) of 1 and 2, showing dihedral angles between opposite phenolic rings linked to the pseudocrown unit. Hydrogen atoms are omitted for clarity. 
difference is the conformational shape of their thiacalix[4]arene core caused by the different arms at the lower rim, which can be exactly identified by the dihedral angle $\left(88.7^{\circ}\right.$ for 1 and $116.2^{\circ}$ for 2) between phenolic rings directly linked to the pseudocrown moiety. This confirms the feasibility of adjusting the pseudocrown cavity by changing the arms, which is the purpose of our design.

Moreover, an optimized structure of $\left[\mathbf{1} \cdot \mathrm{Pb}^{2+}\right]$ showed the binding modes between the receptor and $\mathrm{Pb}^{2+}$ (Fig. 11), where $\mathrm{Pb}^{2+}$ ion well occupied the pseudocrown cavity with the aid of the intraannular carbonyl oxygen atom of the anthraquinone group and nitrogen atoms of both 1,2,3-triazole rings. This confirmed the supposition about the binding sites. Remarkably, the most striking feature of $\left[\mathbf{1} \cdot \mathrm{Pb}^{2+}\right]$ is that the v-like shape of the anthraquinone moiety was turning nearly into a plane. The relevant torsion angles $\mathrm{O} 1-\mathrm{C} 1-\mathrm{C} 2-\mathrm{C} 3$ and $\mathrm{O} 1-\mathrm{C} 1-\mathrm{C} 4-\mathrm{C} 5$ are 179.5 and $179.8^{\circ}$ in $\left[\mathbf{1} \cdot \mathrm{Pb}^{2+}\right]$, respectively, as compared to 153.3 and $155.9^{\circ}$ in $\mathbf{1}$.

In the optimized structure of $\left[\mathbf{1} \cdot \mathrm{Pb}^{2+}\right]$, there are intramolecular $\mathrm{O}-\mathrm{H} \cdots \mathrm{O}$ hydrogen bonds, which can restrict the conformational transformation and fix the size of the pseudocrown cavity. This fact can explain the high specificity of 1 towards $\mathrm{Pb}^{2+}$. Similarly, this increase in the structural rigidity of $\left[\mathbf{1} \cdot \mathrm{Pb}^{2+}\right]$ could rationalize the fluorescence enhancement, which was in agreement with the experimental phenomenon. However, in the case of $\left[2 \cdot \mathrm{Zn}^{2+}\right]$ (Fig. S14, ESI $\dagger$ ), no corresponding hydrogen bonds exist due to the replacement of $\mathrm{OH}$ groups with $\mathrm{OCH}_{2} \mathrm{CO}_{2} \mathrm{Me}$ arms; thus, the thiacalix[4]arene platform has enough flexibility to adjust the size of the pseudocrown cavity, fitting different cations. This may explain why 2 can recognize $\mathrm{Pb}^{2+}$ and $\mathrm{Zn}^{2+}$ ions at the same time.

The recognition properties of $\mathbf{3}$ towards different metal ions were also studied using similar methods. Its absorption band is centered at $386 \mathrm{~nm}$. Changes in the absorption spectra of 3 upon the addition of $\mathrm{Zn}^{2+}, \mathrm{Co}^{2+}$, and $\mathrm{Ni}^{2+}$ were observed, and a new absorption band at $490 \mathrm{~nm}$ appeared (Fig. S15, ESI $\dagger$ ). This result is attributable to the formation of $\left[3 \cdot \mathrm{M}^{2+}\right]\left(\mathrm{M}^{2+}=\mathrm{Zn}^{2+}\right.$, $\mathrm{Co}^{2+}$, and $\mathrm{Ni}^{2+}$ ). The fluorescence spectrum of 3 displays an emission peak at $484 \mathrm{~nm}$ under excitation at $375 \mathrm{~nm}$. Compared with those of $\mathbf{1}$ and $\mathbf{2}$, the red-shifted fluorescence spectrum of $\mathbf{3}$ is ascribed to the dissociative proton of the carboxyl group binding to the carbonyl group of the anthraquinone function.

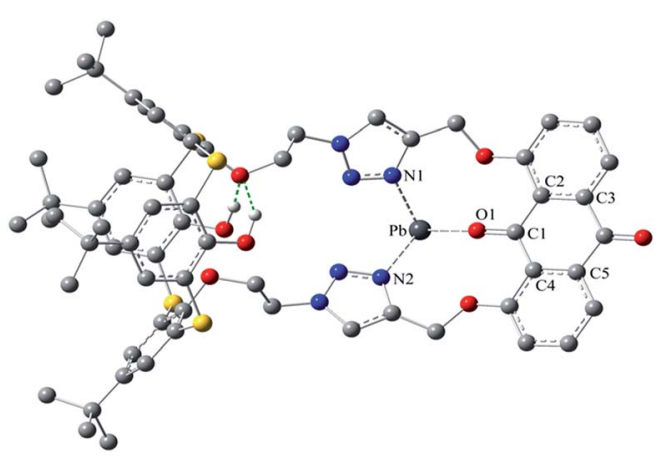

Fig. 11 An optimized structure (AM1/3-21G) of $\left[1 \cdot \mathrm{Pb}^{2+}\right]$, showing coordination modes.
Decreased emission bands were observed upon the addition of $\mathrm{Zn}^{2+}, \mathrm{Co}^{2+}$, and $\mathrm{Ni}^{2+}$ ions to 3 (Fig. S16, ESI $\dagger$ ), which could be ascribed to a PET mechanism. ${ }^{44}$ Moreover, an obvious DPV response of 3 to $\mathrm{Pb}^{2+}, \mathrm{Zn}^{2+}$, and $\mathrm{Cd}^{2+}$ ions was found with a positive potential shift, especially in the case of $\mathrm{Pb}^{2+}$ ions. At present, the selectivity of $\mathbf{3}$ for metal ions is not desirable, but its solubility in aqueous media is improved. Therefore, we believe that better selective receptors can be obtained in the future by loading other water-soluble groups.

\section{Experimental}

\subsection{Reagents and instruments}

All reactions were carried out under a $\mathrm{N}_{2}$ atmosphere using standard Schlenk techniques. DMSO, $\mathrm{MeCN}$, and $\mathrm{CH}_{2} \mathrm{Cl}_{2}$ were distilled under nitrogen over $\mathrm{CaH}_{2}$. $\mathrm{K}_{2} \mathrm{CO}_{3}$, TsCl, $\mathrm{NaOH}$, KI, and 1,8-dihydroxy-9,10-anthraquinone were commercially obtained and used without further purification. ${ }^{1} \mathrm{H}$ and ${ }^{13} \mathrm{C}$ NMR spectra were obtained using a BRUKER ADVANCE 300 spectrometer. IR spectra were obtained using a BIO-RAD FTS-40 spectrometer. Mass spectrometric data were obtained using a HP1100 LCAPI4000 TQ Mass Spectrometer. Elemental analyses were performed using a Perkin-Elmer 2400 analyzer. X-ray analysis was performed via a Bruker Smart Apex CCD diffractometer. Melting points were measured using a Yanaco MP-500 micro melting point apparatus and uncorrected. UV-vis absorption spectra were obtained using a Shimadzu UV-1700 absorption spectrometer. Fluorescence spectra were obtained using an FLS920 fluorescence spectrometer. Electrochemical experiments were performed using a CHI660 electrochemical analyzer.

$p$-tert-Butylthiacalix[4]arene, ${ }^{53}$ 2-azidoethyl-4- $p$-toluenesulfonate, ${ }^{54}$ and 1,8-bis(2-propynyloxy)anthraquinone ${ }^{55}$ were prepared according to literature methods.

\subsection{Synthesis and characterization of I}

A mixture of $p$-tert-butylthiacalix[4]arene $(0.150 \mathrm{~g}, 0.21 \mathrm{mmol})$, 2-azidoethyl-4-methylbenzenesulfonate ( $1.000 \mathrm{~g}, 4.16 \mathrm{mmol}), \mathrm{KI}$ $(0.697 \mathrm{~g}, 4.20 \mathrm{mmol})$, and $\mathrm{K}_{2} \mathrm{CO}_{3}(0.035 \mathrm{~g}, 0.25 \mathrm{mmol})$ in dry acetone $(10 \mathrm{~mL})$ was heated under reflux for $120 \mathrm{~h}$ and cooled down to room temperature. After the removal of the solvent under reduced pressure, the residue was dissolved in $\mathrm{CH}_{2} \mathrm{Cl}_{2}$ and washed with $5 \% \mathrm{HCl}$, saturated $\mathrm{NaHCO}_{3}$, and brine. The organic layer was dried over anhydrous $\mathrm{Na}_{2} \mathrm{SO}_{4}$ and evaporated under reduced pressure. The crude product was purified by flash column chromatography (silica gel, $\mathrm{CH}_{2} \mathrm{Cl}_{2} /$ hexane $=$ $6: 1, R_{\mathrm{f}}=0.4$ ) to obtain the intermediate $\mathbf{I}$ in a moderate $56 \%$ yield as a white solid, mp: $217-218{ }^{\circ} \mathrm{C}$. IR $\left(\mathrm{KBr}, \mathrm{cm}^{-1}\right) \nu_{\text {max }}$ : 3127.12 $(\mathrm{OH}), 2101.00\left(\mathrm{~N}=\mathrm{N}^{+}=\mathrm{N}^{-}\right), 1245.29(\mathrm{Ar}-\mathrm{O}-\mathrm{C}), 1035.52$ (C-O-C). ${ }^{1} \mathrm{H}$ NMR $\left(\mathrm{CDCl}_{3}, 300 \mathrm{~Hz}\right): 0.80(\mathrm{~s}, 18 \mathrm{H}, t-\mathrm{Bu}), 1.36$ (s, $18 \mathrm{H}, t-\mathrm{Bu}), 3.91\left(\mathrm{t}, 4 \mathrm{H}, J=4.91 \mathrm{~Hz}, \mathrm{NCH}_{2}\right), 4.77(\mathrm{t}, 4 \mathrm{H}, J=$ $\left.4.95 \mathrm{~Hz}, \mathrm{OCH}_{2}\right), 6.95$ (s, 4H, Ar-H), $7.69(\mathrm{~s}, 4 \mathrm{H}, \mathrm{Ar}-\mathrm{H}), 7.81$ (s, $2 \mathrm{H}, \mathrm{OH}) .{ }^{13} \mathrm{C}$ NMR $\left(\mathrm{CDCl}_{3}, 75 \mathrm{~Hz}\right): 30.73,31.46,34.01,34.19$, 51.33, 72.52, 122.04, 128.96, 132.75, 134.56, 142.88, 148.32, 155.45, 155.65. Anal. (\%) calcd for $\mathrm{C}_{44} \mathrm{H}_{54} \mathrm{~N}_{6} \mathrm{O}_{4} \mathrm{~S}_{4}: \mathrm{C}, 61.51 ; \mathrm{H}$, 6.33 ; N, 9.78. Found: C, 61.26; H, 6.20; N, 9.71. 


\subsection{Synthesis and characterization of 1}

To a stirred suspension of CuI $(0.014 \mathrm{~g}, 0.08 \mathrm{mmol})$ and $\mathrm{Et}_{3} \mathrm{~N}$ $(0.18 \mathrm{~mL}, 3.02 \mathrm{mmol})$ in $\mathrm{THF} / \mathrm{H}_{2} \mathrm{O}(12 \mathrm{~mL}, \mathrm{v} / \mathrm{v}=3: 1)$, a solution of $5(0.130 \mathrm{~g}, 0.15 \mathrm{mmol})$ in dry THF $(10 \mathrm{~mL})$ and the other solution of 1,8-bis(2-propynyloxy)anthraquinone (0.048 g, 0.15 $\mathrm{mmol})$ in dry THF $(10 \mathrm{~mL})$ were added at the same time. The resulting mixture was stirred for $4 \mathrm{~h}$ at $60{ }^{\circ} \mathrm{C}$. After removal of the solvent under reduced pressure, the residue was dissolved in $\mathrm{CH}_{2} \mathrm{Cl}_{2}$ and washed with $5 \% \mathrm{HCl}$, saturated $\mathrm{NaHCO}_{3}$, and brine. The organic layer was dried over anhydrous $\mathrm{Na}_{2} \mathrm{SO}_{4}$ and evaporated under reduced pressure. The crude product was purified by flash column chromatography (silica gel, $\mathrm{CH}_{2} \mathrm{Cl}_{2}$ / acetone $=2: 1, R_{\mathrm{f}}=0.5$ ) to obtain 1 in $51 \%$ yield as a yellow solid, mp: $247-249{ }^{\circ} \mathrm{C}$. IR $\left(\mathrm{KBr}, \mathrm{cm}^{-1}\right) \nu_{\max }: 3133.03(\mathrm{OH})$, $1672.46(\mathrm{C}=\mathrm{O}), 1586.75(\mathrm{~N}=\mathrm{N}), 1242.81(\mathrm{Ar}-\mathrm{O}-\mathrm{C}), 1040.64(\mathrm{C}-$ O-C). ${ }^{1} \mathrm{H}$ NMR (DMSO- $\left.d_{6}, 300 \mathrm{~Hz}\right): 0.69(\mathrm{~s}, 18 \mathrm{H}, t$-Bu), $1.30(\mathrm{~s}$, $18 \mathrm{H}, t-\mathrm{Bu}$ ), 4.90 (br s, $4 \mathrm{H}, \mathrm{NCH}_{2}$ ), 5.06 (br s, $4 \mathrm{H}, \mathrm{OCH}_{2}$ ), 5.49 (s, $\left.4 \mathrm{H}, \mathrm{OCH}_{2}\right), 6.88(\mathrm{~s}, 4 \mathrm{H}, \mathrm{Ar}-\mathrm{H}), 7.25(\mathrm{~s}, 2 \mathrm{H}, \mathrm{OH}), 7.47-7.68(\mathrm{~m}$, $10 \mathrm{H}, \mathrm{AQ}-\mathrm{H}, \mathrm{Ar}-\mathrm{H}$, overlap), 8.48 (s, $2 \mathrm{H}$, Tri-H). ESI-MS: $m / z[\mathrm{M}]^{+}$ calcd 1174.4, found: $1175.8[\mathrm{M}+1]^{+}, 1198.2[\mathrm{M}+\mathrm{Na}]^{+}$. Anal. (\%) calcd for $\mathrm{C}_{64} \mathrm{H}_{66} \mathrm{~N}_{6} \mathrm{O}_{8} \mathrm{~S}_{4}: \mathrm{C}, 65.39 ; \mathrm{H}, 5.66 ; \mathrm{N}, 7.15$. Found: $\mathrm{C}$, $65.10 ; \mathrm{H}, 5.70 ; \mathrm{N}, 7.18$.

\subsection{Synthesis and characterization of 2}

A suspension of $1(0.120 \mathrm{~g}, 0.10 \mathrm{mmol})$ and $\mathrm{NaH}(0.020 \mathrm{~g}, 0.82$ $\mathrm{mmol})$ in THF ( $6 \mathrm{~mL}$ ) was stirred for $5 \mathrm{~min}$, and then methyl bromoacetate $(0.10 \mathrm{~mL}, 1.02 \mathrm{mmol})$ was added. The resulting mixture was stirred for $20 \mathrm{~h}$ at room temperature. After the removal of the solvent under reduced pressure, the residue was dissolved in $\mathrm{CH}_{2} \mathrm{Cl}_{2}$ and washed with $5 \% \mathrm{HCl}$, saturated $\mathrm{NaHCO}_{3}$, and brine. The organic layer was dried over anhydrous $\mathrm{Na}_{2} \mathrm{SO}_{4}$ and evaporated under reduced pressure. The crude product was purified by flash column chromatography (silica gel, EtOAc/hexane $\left.=1: 1, R_{\mathrm{f}}=0.4\right)$ to obtain compound 2 in $82 \%$ yield as a yellow solid, $\mathrm{mp}: 284-286^{\circ} \mathrm{C}$. $\mathrm{IR}\left(\mathrm{KBr}, \mathrm{cm}^{-1}\right) \nu_{\max }$ : $1759.02(\mathrm{O}-\mathrm{C}=\mathrm{O}), 1673.31(\mathrm{C}=\mathrm{O}), 1587.68(\mathrm{~N}=\mathrm{N}), 1241.83$ (Ar-O-C), 1041.83 (C-O-C). ${ }^{1} \mathrm{H}$ NMR $\left(\mathrm{CDCl}_{3}, 300 \mathrm{~Hz}\right): 0.87$ (s, $18 \mathrm{H}, t-\mathrm{Bu}), 1.38(\mathrm{~s}, 18 \mathrm{H}, t-\mathrm{Bu}), 3.72\left(\mathrm{~s}, 6 \mathrm{H}, \mathrm{CH}_{3}\right), 4.74(\mathrm{~s}, 4 \mathrm{H}$, $\left.\mathrm{OCH}_{2}\right), 4.83\left(\mathrm{t}, 4 \mathrm{H}, J=7.97 \mathrm{~Hz}, \mathrm{NCH}_{2}\right), 5.34\left(\mathrm{~s}, 4 \mathrm{H}, \mathrm{OCH}_{2}\right), 5.45$ $\left(\mathrm{t}, 4 \mathrm{H}, J=7.94 \mathrm{~Hz}, \mathrm{OCH}_{2}\right), 6.97(\mathrm{~s}, 4 \mathrm{H}, \mathrm{Ar}-\mathrm{H}), 7.48$ (d, $2 \mathrm{H}, J=$ $8.22 \mathrm{~Hz}, \mathrm{AQ}-\mathrm{H}), 7.71(\mathrm{t}, 2 \mathrm{H}, J=7.91 \mathrm{~Hz}, \mathrm{AQ}-\mathrm{H}), 7.80$ (s, 4H, Ar$\mathrm{H}), 7.95$ (d, 2H, $J=7.56 \mathrm{~Hz}, \mathrm{AQ}-\mathrm{H}), 8.43$ (s, 2H, Tri-H). ${ }^{13} \mathrm{C}$ NMR $\left(\mathrm{CDCl}_{3}, 75 \mathrm{~Hz}\right): 30.80,31.40,33.97,34.49,49.26,52.17,65.24$, $72.82,72.87,120.36,121.42,124.26,125.27,128.94,129.54$, 130.97, 133.10, 134.04, 134.93, 135.83, 143.55, 147.18, 147.58, 155.82, 158.01, 160.02, 169.41, 181.88, 183.78. ESI-MS: $m / z[\mathbf{M}]^{+}$ calcd 1318.4, found: $1320.1[\mathrm{M}+2]^{+}, 1341.8[\mathrm{M}+\mathrm{Na}]^{+}$. Anal. (\%) calcd for $\mathrm{C}_{70} \mathrm{H}_{74} \mathrm{~N}_{6} \mathrm{O}_{12} \mathrm{~S}_{4}: \mathrm{C}, 63.71 ; \mathrm{H}, 5.65 ; \mathrm{N}, 6.37$. Found: C, 63.52; H, 5.38; N, 6.51.

\subsection{Synthesis and characterization of 3}

To a solution of $2(0.200 \mathrm{~g}, 0.15 \mathrm{mmol})$ in THF $(6 \mathrm{~mL}), \mathrm{KOH}$ $(0.021 \mathrm{~g}, 0.38 \mathrm{mmol})$ dissolved in water $(1 \mathrm{~mL})$ was added, and the mixture was stirred for $17 \mathrm{~h}$ at room temperature. After removal of the solvent under reduced pressure, the residue was dissolved in $\mathrm{CH}_{2} \mathrm{Cl}_{2}$ and washed with $5 \% \mathrm{HCl}$ and brine. The organic layer was dried over anhydrous $\mathrm{Na}_{2} \mathrm{SO}_{4}$ and evaporated under reduced pressure. The crude product was purified by recrystallization to obtain compound 3 in 93\% yield as a yellow solid, mp: $220-222{ }^{\circ} \mathrm{C}$. IR ( $\left.\mathrm{KBr}, \mathrm{cm}^{-1}\right) \nu_{\text {max }}: 1746.04(\mathrm{O}-\mathrm{C}=\mathrm{O})$, $1671.30(\mathrm{C}=\mathrm{O}), 1587.62(\mathrm{~N}=\mathrm{N}), 1242.54(\mathrm{Ar}-\mathrm{O}-\mathrm{C}), 1047.86(\mathrm{C}-$ $\mathrm{O}-\mathrm{C}) .{ }^{1} \mathrm{H} \mathrm{NMR}\left(\mathrm{CDCl}_{3}, 300 \mathrm{~Hz}\right): 0.79(\mathrm{~s}, 18 \mathrm{H}, t-\mathrm{Bu}), 1.30(\mathrm{~s}, 18 \mathrm{H}$, $t$-Bu), 4.53 (br s, $\left.4 \mathrm{H}, \mathrm{OCH}_{2}\right), 4.75\left(\mathrm{~s}, 4 \mathrm{H}, \mathrm{NCH}_{2}\right), 4.90(\mathrm{~s}, 4 \mathrm{H}$, $\mathrm{OCH}_{2}$ ), 5.61 (br s, $4 \mathrm{H}, \mathrm{OCH}_{2}$ ), $6.82(\mathrm{~s}, 4 \mathrm{H}, \mathrm{Ar}-\mathrm{H}), 7.51$ (s, $4 \mathrm{H}, \mathrm{Ar}-$ H), 7.62 (br s, 4H, AQ-H), 7.92 (br s, 2H, AQ-H), 8.43 (s, 2H, Tri$\mathrm{H}) .{ }^{13} \mathrm{C} \mathrm{NMR}\left(\mathrm{CDCl}_{3}, 75 \mathrm{~Hz}\right): 30.76,31.30,34.03,34.42,49.97$, $62.30,71.84,75.60,119.10,119.93,123.24,126.46,128.36$, 129.03 , 133.22, 133.86, 134.37, 136.47, 143.17, 148.02, 148.09, 155.30, 157.47, 157.80, 169.46, 182.34, 183.02. ESI-MS: $m / z[\mathrm{M}]^{+}$ calcd 1290.4, found: $1292.1[\mathrm{M}+2]^{+}, 1313.8[\mathrm{M}+\mathrm{Na}]^{+}$. Anal. (\%) calcd for $\mathrm{C}_{68} \mathrm{H}_{70} \mathrm{~N}_{6} \mathrm{O}_{12} \mathrm{~S}_{4}$ : C, 63.23; H, 5.46; N, 6.51. Found: C, 62.98; H, 5.22; N, 6.33.

\subsection{Crystallography}

Crystal data for $2, \mathrm{C}_{71} \mathrm{H}_{78} \mathrm{~N}_{6} \mathrm{O}_{13} \mathrm{~S}_{4}, M=1351.63$, triclinic, space group $P \overline{1}, a=15.083(4) \AA, b=15.371(4) \AA, c=16.395(4) \AA, \alpha=$ $66.767(3)^{\circ}, \beta=81.148(4)^{\circ}, \gamma=80.089(4)^{\circ}, V=3425.3(14) \AA^{3}, \mu=$ $0.206 \mathrm{~mm}^{-1}, Z=2, T=173(2) \mathrm{K}$, crystal size $0.32 \times 0.31 \times 0.12$ $\mathrm{mm}^{3}, \theta$ range $1.84-25.50^{\circ}$. Herein, 17948 reflections were obtained, of which 12489 reflections were unique $\left(R_{\text {int }}=0.0351\right)$. Final $R$ indices $[I>2 \sigma(I)]: R_{1}=0.0652, \mathrm{w} R_{2}=0.1525, R$ indices (all data): $R_{1}=0.1098, \mathrm{w} R_{2}=0.1796$, and goodness of fit on $F^{2}=$ 1.022. CCDC: 863160.

\subsection{UV-vis/fluorescence tests}

Stock solutions of the metal ions $\left(5.0 \times 10^{-3} \mathrm{M}\right)$ were prepared in MeCN (for 1 and 2) and deionized water (for 3). A stock solution of 1 and $2\left(5.0 \times 10^{-5} \mathrm{M}\right)$ was prepared in $\mathrm{CH}_{2} \mathrm{Cl}_{2}$ / MeCN $(1: 1, \mathrm{v} / \mathrm{v})$. A stock solution of $3\left(5.0 \times 10^{-5} \mathrm{M}\right)$ was prepared in $\mathrm{THF} / \mathrm{H}_{2} \mathrm{O}(9: 1, \mathrm{v} / \mathrm{v}, \mathrm{pH}=7.4$, HEPES). For fluorescence measurements, excitation was provided at $375 \mathrm{~nm}$, and emission was obtained at $427 \mathrm{~nm}, 428 \mathrm{~nm}$, and $484 \mathrm{~nm}$, respectively, for $\mathbf{1}, \mathbf{2}$, and $\mathbf{3}$.

\subsection{Electrochemistry tests}

Electrochemical measurements were performed using a solution of $1,2\left(5.0 \times 10^{-4} \mathrm{M}\right)$ in $\mathrm{CH}_{2} \mathrm{Cl}_{2} / \mathrm{DMSO}(3: 1, \mathrm{v} / \mathrm{v})$, and 3 (5.0 $\left.\times 10^{-4} \mathrm{M}\right)$ in $\mathrm{THF} / \mathrm{H}_{2} \mathrm{O}(9: 1, \mathrm{v} / \mathrm{v}, \mathrm{pH}=7.4, \mathrm{HEPES})$ with $0.1 \mathrm{M} n$ $\mathrm{Bu}_{4} \mathrm{NPF}_{6}$ as a supporting electrolyte, $\mathrm{Hg} / \mathrm{Hg}_{2} \mathrm{Cl}_{2}$ as the reference electrode, along with platinum working and auxiliary electrodes. Stock solutions of the metal ions $\left(5.0 \times 10^{-2} \mathrm{M}\right)$ were prepared in DMSO (for 1 and 2) and deionized water (for 3). CV was scanned at $200 \mathrm{mVs}^{-1}$. DPV was carried out with a $50 \mathrm{mV}$ pulse amplitude at a scan rate of $5 \mathrm{mVs}^{-1}$.

\subsection{Theoretical calculations}

The theoretical calculations were performed using the Gaussian 03 software package. The molecular structures of receptors 1 and 2 as well as their complexes were fully optimized using the AM1 (Austin Model vs.1) method with the tight convergence 
criteria in the gas-phase. The influence of counter-ions was not considered. This semi-empirical method is popularly used for the modeling of large molecular systems as it is a very convenient and time-saving technique.

\section{Conclusions}

In summary, three novel cone thiacalix[4]pseudocrown receptors 1-3, bearing an anthraquinone function as an optical and electrochemical sensing probe and two 1,2,3-triazole rings as key binding sites, have been prepared. Through accommodating the crown cavity to alter the binding ability towards various ions, two cone thiacalix[4]pseudocrown receptors, $\mathbf{1}$ and 2, were obtained to monitor $\mathrm{Pb}^{2+}$ and $\mathrm{Zn}^{2+}$ ions, respectively, with high selectivity. This provides an insight into the regulation of the binding specificity of receptors by exchanging their side arms. Moreover, the better water-solubility of $\mathbf{3}$ is of importance for further development of this type of receptors.

\section{Acknowledgements}

This work was financially supported by the National Natural Science Foundation of China (grant No. 21372147) and the Undergraduate Innovative Research Training Program of Shandong Normal University (grant No. 201610445067).

\section{Notes and references}

1 A. Caballero, R. Martínez, V. Lloveras, I. Ratera, J. VidalGancedo, K. Wurst, A. Tárraga, P. Molina and J. Veciana, J. Am. Chem. Soc., 2005, 127, 15666-15667.

2 K. Huang, H. Yang, Z. Zhou, M. Yu, F. Li, X. Gao, T. Yi and C. Huang, Org. Lett., 2008, 10, 2557-2560.

3 F. Ge, H. Ye, J.-Z. Luo, S. Wang, Y.-J. Sun, B.-X. Zhao and J.-Y. Miao, Sens. Actuators, B, 2013, 181, 215-220.

4 C. Arivazhagan, R. Borthakur and S. Ghosh, Organometallics, 2015, 34, 1147-1155.

5 Y. Fang, Y. Zhou, Q. Rui and C. Yao, Organometallics, 2015, 34, 2962-2970.

6 R. J. P. Williams and J. J. R. F. da Silva, Coord. Chem. Rev., 2000, 200-202, 247-348.

7 J. J. R. Fraústo da Silva and R. J. P. Williams, Zinc: Lewis Acid Catalysis and Regulation, in The Biological Chemistry of Elements: The Inorganic Chemistry of Life, Oxford University Press, New York, 2nd edn, 2001.

8 P. Jiang and Z. Guo, Coord. Chem. Rev., 2004, 248, 205-229.

9 N. C. Lim, H. C. Freake and C. Brückner, Chem.-Eur. J., 2005, 11, 38-49.

10 Z. Xu, J. Yoon and D. R. Spring, Chem. Soc. Rev., 2010, 39, 1996-2006.

11 A. R. Flegal and D. R. Smith, Environ. Res., 1992, 58, 125-133.

12 H. N. Kim, W. X. Ren, J. S. Kim and J. Yoon, Chem. Soc. Rev., 2012, 41, 3210-3244.

13 C.-Y. Li, Y. Zhou, Y.-F. Li, X.-F. Kong, C.-X. Zou and C. Weng, Anal. Chim. Acta, 2013, 774, 79-84.

14 T. Sun, Q. Niu, Z. Guo and T. Li, Tetrahedron Lett., 2017, 58, 252-256.
15 N. Morohashi, F. Narumi, N. Iki, T. Hattori and S. Miyano, Chem. Rev., 2006, 106, 5291-5316.

16 M. Kumar, N. Kumar and V. Bhalla, Dalton Trans., 2013, 42, 981-986.

17 R. Kumar, Y. O. Lee, V. Bhalla, M. Kumar and J. S. Kim, Chem. Soc. Rev., 2014, 43, 4824-4870.

18 H. Tomiyasu, J.-L. Zhao, X.-L. Ni, X. Zeng, M. R. J. Elsegood, B. Jones, C. Redshaw, S. J. Teat and T. Yamato, RSC Adv., 2015, 5, 14747-14755.

19 M. Yamada, M. R. Gandhi, U. M. R. Kunda and F. Hamada, J. Inclusion Phenom. Macrocyclic Chem., 2016, 85, 1-18.

20 J.-L. Zhao, C. Wu, X. Zeng, S. Rahman, P. E. Georghiou, M. R. J. Elsegood Mr, T. G. Warwick, C. Redshaw, S. J. Teat and T. Yamato, ChemistrySelect, 2016, 1, 1541-1547.

21 M. Zhao, J. Lv and D.-S. Guo, RSC Adv., 2017, 7, 10021-10050. 22 S. M. Darjee, D. R. Mishra, K. D. Bhatt, D. J. Vyas, K. M. Modi and V. K. Jain, Tetrahedron Lett., 2014, 55, 7094-7098.

23 M. Kumar, N. Kumar and V. Bhalla, Sens. Actuators, B, 2012, 161, 311-316.

24 F. Miao, J. Zhan, Z. Zou, D. Tian and H. Li, Tetrahedron, 2012, 68, 2409-2413.

25 J.-L. Zhao, H. Tomiyasu, C. Wu, H. Cong, X. Zeng, S. Rahman, P. E. Georghiou, D. L. Hughes, C. Redshaw and T. Yamato, Tetrahedron, 2015, 71, 8521-8527.

26 M.-Q. Ran, J.-Y. Yuana, Y.-H. Zhao, L. Mou, X. Zeng, C. Redshaw, J. L. Zhao and T. Yamato, Supramol. Chem., 2016, 28, 418-426.

27 D.-S. Guo, Z.-P. Liu, J.-P. Ma and R.-Q. Huang, Tetrahedron Lett., 2007, 48, 1221-1224.

28 B.-T. Zhao, Z. Zhou, Z.-N. Yan, E. Belhadj, F. L. Derf and M. Sallé, Tetrahedron Lett., 2010, 51, 5815-5818.

29 V. K. Gupta, B. Sethi, R. A. Sharma, S. Agarwal and A. Bharti, J. Mol. Liq., 2013, 177, 114-118.

30 V. Lamare, J.-F. Dozol, P. Thuéry, M. Nierlich, Z. Asfari and J. Vicens, J. Chem. Soc., Perkin Trans. 2, 2001, 1920-1926.

31 A. Muravev, F. Galieva, O. Bazanova, D. Sharafutdinova, S. Solovieva, I. Antipin and A. Konovalov, Supramol. Chem., 2016, 28, 589-600.

32 A. Ghosh, D. A. Jose and R. Kaushik, Sens. Actuators, B, 2016, 229, 545-560.

33 D. Bethell, G. Dougherty and D. C. Cupertino, J. Chem. Soc., Chem. Commun., 1995, 675-676.

34 D. Y. Han, J. M. Kim, J. Kim, H. S. Jung, Y. H. Lee, J. F. Zhang and J. S. Kim, Tetrahedron Lett., 2010, 51, 1947-1951.

35 C. W. Tornøe, C. Christensen and M. Meldal, J. Org. Chem., 2002, 67, 3057-3064.

36 V. V. Rostovtsev, L. G. Green, V. V. Fokin and K. B. Sharpless, Angew. Chem., Int. Ed., 2002, 41, 2596-2599.

37 C. Wang, D. Ikhlef, S. Kahlal, J.-Y. Saillard and D. Astruc, Coord. Chem. Rev., 2016, 316, 1-20.

38 F. W. B. van Leeuwen, H. Beijleveld, H. Kooijman, A. L. Spek, W. Verboom and D. N. Reinhoudt, J. Org. Chem., 2004, 69, 3928-3936.

39 S. G. Bott, S. J. Obrey, A. P. Marchand and K. A. Kumar, J. Chem. Crystallogr., 1996, 26, 677-681.

40 A. Bondi, J. Phys. Chem., 1964, 68, 441-451. 
41 S. Maruyama, K. Kikuchi, T. Hirano, Y. Urano and T. Nagano, J. Am. Chem. Soc., 2002, 124, 10650-10651.

42 A. P. de Silva, H. Q. N. Gunaratne, T. Gunnlaugsson, A. J. M. Huxley, C. P. McCoy, J. T. Rademacher and T. E. Rice, Chem. Rev., 1997, 97, 1515-1566.

43 B. Valeur and I. Leray, Coord. Chem. Rev., 2000, 205, 3-40. 44 J. S. Kim and D. T. Quang, Chem. Rev., 2007, 107, 3780-3799. 45 P. Job, Ann. Chim., 1928, 9, 113-203.

46 V. M. S. Gil and N. C. Oliveira, J. Chem. Educ., 1990, 67, 473478.

47 Y. Liu, B.-H. Han and Y.-T. Chen, J. Phys. Chem. B, 2002, 106, 4678-4687.

48 J. Jia, X. Tang, Y. He, M. Zhang and G. Xing, Chin. J. Org. Chem., 2012, 32, 1803-1811.

49 Y. Xu, L. Xiao, S. Sun, Z. Pei, Y. Peia and Y. Pang, Chem. Commun., 2014, 50, 7514-7516.

50 A. Sil, A. Maity, D. Giri and S. K. Patra, Sens. Actuators, B, 2016, 226, 403-411.

51 M. J. Frisch, G. W. Trucks, H. B. Schlegel, G. E. Scuseria, M. A. Robb, J. R. Cheeseman, J. A. Montgomery Jr, T. Vreven, K. N. Kudin, J. C. Burant, J. M. Millam, S. S. Iyengar, J. Tomasi, V. Barone, B. Mennucci, M. Cossi, G. Scalmani, N. Rega, G. A. Petersson, H. Nakatsuji, M. Hada, M. Ehara, K. Toyota, R. Fukuda, J. Hasegawa,
M. Ishida, T. Nakajima, Y. Honda, O. Kitao, H. Nakai, M. Klene, X. Li, J. E. Knox, H. P. Hratchian, J. B. Cross, V. Bakken, C. Adamo, J. Jaramillo, R. Gomperts, R. E. Stratmann, O. Yazyev, A. J. Austin, R. Cammi, C. Pomelli, J. W. Ochterski, P. Y. Ayala, K. Morokuma, G. A. Voth, P. Salvador, J. J. Dannenberg, V. G. Zakrzewski, S. Dapprich, A. D. Daniels, M. C. Strain, O. Farkas, D. K. Malick, A. D. Rabuck, K. Raghavachari, J. B. Foresman, J. V. Ortiz, Q. Cui, A. G. Baboul, S. Clifford, J. Cioslowski, B. B. Stefanov, G. Liu, A. Liashenko, P. Piskorz, I. Komaromi, R. L. Martin, D. J. Fox, T. Keith, M. A. Al-Laham, C. Y. Peng, A. Nanayakkara, M. Challacombe, P. M. W. Gill, B. Johnson, W. Chen, M. W. Wong, C. Gonzalez and J. A. Pople, Gaussian 03, revision B.03, Gaussian, Inc., Wallingford, CT, 2004.

52 M. J. S. Dewar, E. G. Zoebisch, E. F. Healey and J. J. P. Stewart, J. Am. Chem. Soc., 1985, 107, 3902-3909.

53 H. Kumagai, M. Hasegawa, S. Miyanari, Y. Sugawa, Y. Sato, T. Hori, S. Ueda, H. Kamiyama and S. Miyano, Tetrahedron Lett., 1997, 38, 3971-3972.

54 B. Carboni, M. Vaultier and R. Carrié, Tetrahedron, 1987, 43, 1799-1810.

55 H. Sharghi, R. Khalifeh and M. M. Doroodmand, Adv. Synth. Catal., 2009, 351, 207-218. 